\title{
Katarzyna Taborska, Lektury polimedialności. Studium odbioru. Wydawnictwo Naukowe PWSZ im. Jakuba z Paradyża w Gorzowie Wielkopolskim, Gorzów Wielkopolski 2015, ss. 158.
}

Językoznawca jako recenzent jest tutaj w kłopocie, bowiem istotny problem nasuwa się już przy genologicznej charakterystyce książki Katarzyny Taborskiej. Według autorki (s. 25) p o dręc znik to przekaz autorytatywny. Jego autor nie zakłada dyskusji i polemik z projektowanymi odbiorcami. Natomiast jej praca jest nie p odręc znikiem, lecz a p odr ę c z n i k i e m, który cechuje się narracją otwartą oraz dyskusją nad prezentowaną problematyką. Polimedialność jako termin ma w intencji autorki charakter humanistyczny, natomiast multimedialność - charakter technologiczny (s. 13). Dziś zamiast o p oli m e dia lności, można już mówić o panmedialności 'powszechnej obecności bądź „nadobecności” różnorodnych mediów i przekazów medialnych’: „Wszechmedialność (panmedialność) zdaje się charakteryzować współczesność tak, jak katedry symbolizują średniowiecze" (s. 13).

Sama autorka tak określa cele i założenia swojej pracy:

Lektury polimedialności powinny zachęcać do zadawania pytań (...). Opracowanie powstało jako wstęp do zajęć z zakresu kultury medialnej prowadzonych w ramach studiów podyplomowych (m.in. bibliotekoznawczych) projektowanych dla słuchaczy, którzy są absolwentami zarówno wydziałów humanistycznych, jak i matematyczno-przyrodniczych. Lektury polimedialności mają ułatwić stworzenie integrującego języka opisu tekstów i zjawisk medialnych: takiego języka, który będzie przyjmowany - niekoniecznie bezdyskusyjnie (sic!) - przez reprezentantów różnych kierunków studiów. Metodycznie ten wspólnotowy kod, przynajmniej jako punkt odniesienia, jest niezbędny do podjęcia humanistycznego namysłu nad medialnością, którego celem jest rozwijanie umiejętności kształtowania świadomego odbioru przekazów pośrednich (s. 17-18).

Czuje jednak autorka potrzebę dookreślenia pojęcia lektury polimedialności, co czynni nieco dalej:

Słowo polimedialność (wielomedialność) - w proponowanym tu ujęciu - odnosi się (...) zarówno do rzeczywistości, dla której typowe jest upowszechnienie się różnych typów przekazów pośrednich (XX wiek), jak i czasu rewolucji medialnej przełomu XX i XXI wieku - okresu nasilającej się dominacji przekazów cyfrowych i ustępujących, choć jeszcze ważnych, analogowych (np. radia). Określenie 'lektury polimedialności’ oznacza zatem jednocześnie przekazy medialne 
i utrwalone akty medialne funkcjonujące w określonej rzeczywistości medialnej, jak i różne sposoby odbioru świata polimedialnego (s. 27).

Autorka jest oczywiście świadoma istnienia zjawiska swoistego analfabetyzmu medialnego:

(...) każdy z żyjących w XXI wieku jest potencjalnym analfabetą funkcjonalnym w świecie mediów - tzn. może nie umieć za pomocą nowego nośnika przekazać i odebrać komunikatu. Chodzi o to, że mamy do czynienia z permanentną możliwością pojawienia się nowych urządzeń medialnych, które wymagają nauczenia się ich obsługiwania. Wielu woli nawet zrezygnować z nowszych modeli komórek niż opanowywać ich instrukcje od początku. Odrębnym zagadnieniem są badania, dość już zresztą zaawansowane, nad funkcjonalnymi analfabetyzmami cyfrowymi (s. 31-32).

W tej sytuacji zróżnicowanych kompetencji medialnych tym sympatyczniej brzmi deklaracja, którą można chyba uznać za swoiste credo autorki:

(...) w opracowaniu ważniejsze od ,prawd gotowych” są inspiracje, hipotezy, innymi słowy: punkty wyjścia do dyskusji. Czytelnik może odrzucić zamieszczone w książce propozycje odbioru medialności oraz opisu jej doświadczania i (...) stworzyć własne projekty analizy przekazów pośrednich (s. 32).

Na koniec dodam, ze językoznawców zainteresuje szczególnie passus terminologiczny (rozdział Mediarze, mediaci, medioplaści ...W kręgu terminów, s. 37-48), translatologów - rozdział Transpozycje translatorskie (s. 89-95), medioznawców - refleksje nad typem obiegów literackich czy medialnych oraz na temat umiejętności (sztuki) korzystania z zasobów wiedzy zawartych na przykład w encyklopediach internetowych (s. 101-108), wreszcie wszystkich humanistów - refleksje na temat tego, co autorka nazywa kulturą redukcji czy na temat polskiego kanonu kulturowego (s. 1909-120). 